\title{
Career Counseling and Vocational Psychology in Portugal: A Political Perspective
}

\author{
Eduardo J. R. Santos and Joaquim Armando Ferreira \\ University of Coimbra, Portugal
}

\begin{abstract}
In this article, we present an overview of the political context of vocational psychology and career counseling in Portugal. The essence of our position is that career counseling needs to encompass all the major tasks of personal and social development, beyond the traditional focus on primarily vocational/occupational goals. Given the importance of social and political factors that are apparent in an analysis of the Portuguese climate within career development, we propose that vocational psychology must go beyond a conceptualization of vocational behavior and intervention based on a person-environment fit model and must try to enhance strategies for the development of persons in a broader sense. We further propose that we need to provide career counseling not only at critical decision points, but throughout the life-span, and should not focus merely on occupational details, but on all matters of the development of the person as a whole. Finally, we suggest a perspective on career counseling and vocational psychology that is more responsive to our cultural and historical context and which is sensitive to the reality of a new political era in Portugal. () 1998 Academic Press
\end{abstract}

In our opinion, career development theory and practice cannot, and should not, be viewed solely as a technical and scientific enterprise. Above all, vocational theory and career counseling practice are rooted in a cultural framework that must be understood in the context of a society's historical evolution (cf. Richardson, 1993). Discourse in our field necessarily involves a political perspective on a vast array of socioeducational issues regarding the personal development of children, youngsters, and adults (Sampson, 1993). The perspective that we hope to advance in this article is embedded in the European Union concept of lifelong education and training, which we believe will help the field of vocational psychology develop potentially new and important conceptual frameworks and intervention strategies. Considering that Portugal is a new democracy, and knowing the importance of education and training in strengthening the social

We express our gratitude to David L. Blustein, Richard F. Haase, and Meryl A. Levin for their comments, suggestions, editorial help, and encouragement throughout all phases of this article's development.

Correspondence concerning this article should be addressed to either of the two authors at the Faculdade de Psicologia e de Ciências da Educação, Universidade de Coimbra, Rua do Colégio Novo, 3000 Coimbra, Portugal. 
development of countries, the conceptual context of lifelong learning appears to be of a great importance for people.

As we see it, the primary goal of career counseling should be to enable individuals to be fully empowered citizens who are capable of deciding about their future (Miller-Tiedeman \& Tiedeman, 1986, 1990). In other words, career counseling should encourage "citizenship,', or social responsibility, wherein one develops the capacity to influence the "polis," or the population as a whole (according to Greek etymology). Citizenship, and the solid development of work values among youth, may be promoted through the conjoint efforts of counselors, teachers, and parents. Given that educational and home environments may differ with regard to the importance placed on certain educational and vocational goals, counselors may also need to make an effort to bridge the gap between these differences and enlist the help of parents in the process.

Therefore, a perspective on career counseling that recognizes the importance of the political climate is recommended. In this article, we hope to demonstrate the importance of adopting a broader view of career counseling and vocational psychology, expanding the scope of the career intervention, and connecting it with the "noble" field of politics. In effect, by using the example provided by the rapid and still evolving changes within Portugal, we intend to develop a political perspective within career development. We view the analysis that follows as a narrative that illustrates the inherent and often subtle, yet pervasive, influence of the political milieu on career development theory, practice, and research.

\section{THE EUROPEAN UNION'S CONCEPT OF LIFELONG EDUCATION AND TRAINING: POLITICAL ROOTS AND RELATIONSHIP} TO CAREER COUNSELING

We begin our discussion by reviewing the European Union concept of lifelong education, and training, which we believe brings our field a valuable opportunity for significant and necessary theoretical and practice innovations. This concept is an extension of the concept of "lifelong learning," adopted by the Council of Ministers of the European Union in 1995; in short, this concept addresses the process by which the continuous acquisition of knowledge and skills will enhance the personal development of individuals and society (Comissão das Comunidades Europeias, 1995). The aim of these concepts is to provide, through continuing learning, education, and training, the conditions for maximum personal and social development of individuals and communities. As such, learning, education, and training are viewed as the tools for the politics of personal and social development. Learning, education, and vocational training are not just concepts associated with the sociocultural system, but represent a concrete way of giving people freedom to express themselves in attaining their legitimate vocational, occupational, and personal aspirations.

Given the foundation established by the commitment to lifelong learning, education, and training, counseling practices are not conceived as exclusively associated with purely educational and/or scholarly issues. In contrast, career 
counseling must necessarily also address wider issues concerning training across the life span (Vondracek, Lerner, \& Schulenberg, 1986). Our position is that lifelong education and training provides a means of addressing the dramatic sociocultural changes that we are experiencing in Portugal today to which our profession is being asked to respond with meaningful theories and intervention strategies (Savickas, 1993).

\section{FROM THE RURAL ERA TO A NEW DEMOCRACY: CHANGE AND DIVERSITY CHALLENGES}

In order for the reader to understand our perspective, we should underscore that our socioeconomic context in Portugal is defined by our current striving toward the professional world. Moreover, we have evolved from a world that was almost exclusively structured around an agricultural and handicraft economy (i.e., the rural world of our ancestors in Portugal) to a more diversified economic structure. In this context, the family was the major educational institution, in partnership with a small community, where school (when it existed) assumed a joint responsibility for education with both one's family and community. Moreover, access to the professions that required further education was generally inherited from the family. When one's vocational aspirations were essentially blunted, one might leave to do something totally different, launching into a somehow, "romantic" adventure (Neff, 1985; Savickas, 1995, 1996).

With a few exceptions, agricultural societies are disappearing in the Western world. In Portugal, the agricultural world still represents a significant part of our social background. However, the socioeconomic stability of the agricultural society within Portugal is being threatened by the emergence of vocational behaviors that contrast radically with other forms of social and professional organizations (Giddens, 1991). We think that in the past it made little sense to talk about vocational counseling in an agricultural society, because vocation arose primarily due to romantic ideals, and the range of freedom of choice was limited. Currently, the clash between the lifestyles of both young people and adults from agricultural societies and those of the nonagrarian, modern world of work presents a true challenge to career counseling. This challenge is particularly apparent when performing counseling work in a small countryside village, which contrasts sharply with counseling in a modern village, which, in turn, represents a different context from that of a large city (Boutinet, 1992). In earlier times, vocational counseling was merely a task of idealizing the individual in a newborn world.

At present, the entire social, political, and cultural context of the individual has become far more complex (Boutinet, 1986), with corresponding changes needed in the design and delivery of vocational counseling services. In Portugal, the radical social shift that occurred after the 1974 revolution brought these issues into much sharper focus. We experienced not only a major shift in the sociocultural fabric of Portuguese life-from fascism to freedom- but we also witnessed the emergence of a vast array of different cultural lifestyles. A more liberal and 
diverse society was born, the complexity of decisions to be made increased, and the work with the "decider" became much more important. It is in this context of increased complexity, resulting from the end of the colonial war and an openness to different cultural and democratic realities (i.e., freedom of speech, freedom of the press, and freedom for political parties, etc.), that an educational "boom" occurred, thus creating a great number of new and different options for individuals.

An increasingly complex occupational system also emerged. These greater opportunities, however, posed challenges to traditional lifestyles, and in some cases were completely contrary to established work values. For example, the increased openness also was associated with more widespread drug use, a problem which now needs to be addressed by counselors throughout society, including career counselors and career-oriented psychologists.

\section{FROM FACTORIES TO SCHOOLS: THE IDEA OF CAREER}

With the advent of urban and industrial economies in Portugal, other major social changes began to take place. The population began moving from the countryside to the cities. Autonomous employment and a wide array of jobs started to disappear, with "bosses" increasingly dominating the hegemony of a production process that was no longer centered in hand-crafted enterprise (Schein, 1978). Large bureaucratic organizations, where professional performance was oriented toward hierarchical career progression, were becoming more prominent in Portugal. The ideal career track was no longer to pursue a handicraft, family-based, or socially sanctioned earlier tradition, but to struggle for a successful career involving work that was, by nature, quite impersonal. Schools that also began to take on a more specialized and hierarchical pattern lost their familial-communitarian style and were restructured as platforms for technical preparation for the world of work-real "assembly-lines" for the production of future workers (Hall, 1976).

Responding to these changes, our "educational culture" become more focused on implementing earlier decision points for youngsters. For example, the earliest decision point we have is in the 9th grade, where 15-year-old students have to make important decisions among different major branches of study, which involves long term consequences for future areas of education, training, and work. Facing the uncertainty that characterizes the present social situation, the work with the decider seems to us to be of particular importance, especially in preparing for the necessary readjustments we need to make everyday in our projects, as we will see in the next section.

\section{THE PERMANENT CHANGE: THE BASIS FOR LIFELONG CAREER COUNSELING}

As we approach the end of the century, we are witnessing again significant and radical changes in the structure of both the working world and the economy. Industrial societies still dominate, even if they are different from those at the 
beginning of the century. In effect, the pace of change that has affected rural Portugal is continually affecting our industrial economics, resulting in evershifting new forms of social, political, and cultural organization (Hotchkiss \& Borow, 1990).

In Portugal, large organizations, structured according to bureaucratic models, are disappearing or diminishing in size ("downsizing"), while new forms of work organization are constantly appearing. There are fewer individuals in "lifetime" professions, temporary work is increasing, distance work is growing, and team work and goal-oriented work are increasing; in fact, there are those who propose that career, as we have known it, is a dying phenomenon.

There are no longer any clearly delineated formal hierarchical structures within an organization with which to seek upward mobility. Instead, we find production systems that perform strategic configuration changes through reengineering processes. Predictability is less of a reality in the working world everyday; contingency and randomness that demand considerable individual and organizational flexibility have become far more common experiences in vocational life (Godet, 1991).

Such a landscape requires people with the ability to manage their careers with enough adaptability to skillfully negotiate changes, to be able to transfer competencies from one work setting to another, and to continually adapt to change. This context, which is occurring in Portugal and in many other sections of the industrialized and postindustrialized economies, provides new challenges to counseling, education, and training (Herr, 1990).

The concept of lifelong career counseling is very relevant to these circumstances. In other words, we need a conceptualization of counseling that will enable us to address the different stages of vocational development, the different social roles we perform throughout our lives, and the different scenarios of society and culture, in an integrated manner.

\section{THE INTERFACE BETWEEN SOCIAL AND PERSONAL NEEDS: A CULTURE OF CONTINUITY AND DEVELOPMENT}

We wonder, are we ready to face and to cope with these complex realities? Are our schools, our educational, training, and counseling systems, also ready to adapt to the changing realities that we face? What answers do we have, for instance, to those families that have experienced the major socioeconomic and cultural disruptions that are characteristic of this "end of the century" period? Also, how can our existing systems deal with the phenomenon of unemployment and its evident negative impact on human life experiences? To what extent does counseling work in tandem with families? Does counseling prepare youngsters to take over a trade that may disappear abruptly? And how does counseling fit into the current panoply of educational and training systems (Watts, Stern, \& Deen, 1992)?

Specifically, in Portugal we face the major problems of the chronically unemployed persons, choice of a first job, and the development of small private 
business. All of these problems are relevant to career counseling which is concerned with enhancing the ability to choose the most optimal array of options, but more fundamentally, enhancing the ability to cope with complex and changing work environments.

These questions, when considered collectively, surely represent research trends for the future (Hackett \& Lent, 1992), because all of these questions have become compelling and challenging for families, schools, industrial concerns, work environments, and lifelong learning and training.

As we consider such complex and fundamental issues, we are faced with the question of what career counseling and vocational psychology has to offer in this sea of change? Without question, these challenges will engender a real and renewed appraisal of a broad set of existing assumptions and perspectives within career counseling and vocational psychology.

In developing this position further, it seems to us that contemporary counseling ought to be increasingly more concerned with occupational socialization (Borow, 1986). In this manner, career counseling can help people develop their identity (with particular relevance to the vocational identity) and find meaning in their lives in a world of work where the "adjustment logic" is less prevalent (Savickas, 1991).

For example, in the Portuguese system of college entrance, students may not be accepted to the major of their choice due to "numerus clausus," or limited entrance to various disciplines. Alternatively, once accepted to a chosen major, students have little to no opportunity to make a change if they are not satisfied with their choice. Therefore, vocational counseling at the high school level and beyond needs to focus on such skills as flexibility and other more general work ethics to be applied over a lifetime. In addition, the higher education system also needs to move towards greater flexibility in allowing students greater opportunity to explore their interests prior to, and once admitted to, a course of study.

Therefore, according to this perspective, we propose a contemporary reaction and readaptation movement in guidance, constructed around the new sociocultural contexts (Arthur, Hall, \& Lawrence, 1989) for which the concept of lifelong education and training represents a paradigm. Only with a lifelong perspective on career counseling, and a developmental approach for vocational psychology, can we face our unique political situation in Portugal-openness to a liberal view of society in a context of an extremely high rate of change occurring as a consequence of the major social shifts that we have experienced after 1974.

Work and careers can no longer to be regarded as objective facts, but must be seen as realities experienced subjectively (Blustein \& Noumair, 1996; Cochran, 1990, 1992), which form the constructive basis of our sensations, symbolisms, and fantasies. Organizations are viewed today as systems characterized by an organizational climate that provides a sort of anthropomorphized identity, in which feelings, values, and other humanlike attributes are transferred, rather than being seen as labor-based entities (Diamond, 1993).

To provide career interventions in contemporary postindustrial cultures, it is 
necessary today to understand the nature of work in relation to each individual worker considered within a context of social, cultural, and economic diversity. Career interventions must focus on, and interpret, the meaning of work in people's lives (Richardson, 1993; Silbereisen \& Todt, 1993). To provide career interventions, one must be able to help clients learn about the world of work and to learn about the "I', who searches, explores, and affirms itself within a socially and culturally embedded process of development (Blustein, 1994). Career counseling must attend to individuality within a sociocultural network, must concern itself with the introjection of the "doing," into the "being," and must help individuals build personalized meanings for work. This view of the process of career counseling is as much psychotherapeutic as it is career intervention (Blustein \& Spengler, 1995; Carlsen, 1988).

Indeed, we assert that both career counseling and psychotherapy have, in part, identical outcomes with regard to well-being and quality of life. For example, the psychosocial drama we experience with long-term unemployed individuals in Portugal obliges us to structure our interventions around a convergence of personal and vocational issues. Many such individuals, after losing their jobs and waiting helplessly for another, have a diminished self-image and self-esteem and are at risk for homelessness. Another example where it would be useful to establish an interface between personal and career issues is in the treatment of occupational stress syndromes (i.e., interpersonal conflicts, depression, substance abuse).

In sum, we believe that the training of counselors in Portugal should include common core concepts and skills which can be applied to the reciprocal areas of work and personal development. To this end, collaboration between career counselors and psychotherapists should be encouraged in order to promote an understanding of the interface between these issues and the appropriate domain of intervention.

In education and training in Portugal, we are faced with the need to develop strategies for addressing a wide range of social circumstances that individuals transverse as they move through their own unique developmental processes (Paixão \& Santos, 1992; Santos \& Paixão, 1995; Young, 1984). No longer will counseling, education, and training be able to rely upon a vision of linear vocational and career development or on an expectation of a stable world. Vocational psychology must do much more than aid in the search for, and maintenance of, a job. It will be necessary to endow all people, from schools to professional training centers, with employability competencies, lifelong learning competencies, and competencies to perform and adapt to the multiple transitions required by today's world (Blustein, Phillips, Jobin-Davis, Finkelberg, \& Roarke, 1997; Lotto, 1986; Watts, 1992).

We also need to convey to our children the idea that we are living in a working society, but also that work is not everything in relation to one's overall goal of leading a healthy and happy life (Black, 1988; Herr, 1989; Kalimo \& Vuori, 1991; Osipow, 1979; Osipow \& Fitzgerald, 1993). In actuality, we need to 
inform children that there are multiple kinds of work-some more stable, others less stable, those that yield more satisfaction, those that result in less satisfaction-and that within this multiplicity, it is possible to find ourselves as persons (Blustein, Devenis, \& Kidney, 1989; Dorn, 1992; Vondracek, 1992). It is also necessary to prepare youngsters in the basic competencies demanded by increasingly challenging production and service tasks of the contemporary labor market (e.g., reading, numeracy, learning to learn, learning to transfer knowledge, learning to tolerate failures) (Blustein, Finkelberg, Ketterson, Schawm, \& Skau, in press). As career counselors, we must accompany adults through their lifelong journey, in a lifetime that may sometimes become too long and turn into frustration and disillusion, by motivating them to begin new starts, tolerate detours, and to consider other life trajectories (Nuttin, 1987).

Career counseling and vocational psychology, embedded in the lifelong education and training context, must prepare people to deal with different authority relationships, different organizational structures, different kinds of emotional environments, different group and personal relationships, conflicts, different organizational and political strategies, different work settings, and must prepare them to express themselves vocationally within this labyrinth (Dalton, 1989; Nystrom \& McArthur, 1989).

As our discussion has suggested, the role of the political and cultural climate in which individuals locate their lives has vast and significant implications for a wide array of vocational behaviors, attitudes, and experiences. The culture of a country provides a means for individuals to define their interactions and tasks (Cushman, 1995) with work-related experiences representing perhaps the most visible crucible of the impact of cultural and political forces. Given the centrality of culture in career development (Blustein \& Noumair, 1996; Richardson, 1993; Savickas, 1993), we propose that human resources should be developed, trained, and managed with an explicit focus on cultural and political factors (Ulrich \& LaFasto, 1995). Moreover, it is through culture that we develop ourselves and our organizations. Identity and individuality is something acquirable and expressible only by culture (Cushman, 1995). Through culture, societies are able to move forward autonomously (Cushman, 1995) and counseling can contribute substantially to this process.

\section{CONCLUSION: THE POLITICS OF VOCATIONS AND EMPOWERMENT}

It is necessary to learn through life how to position and express ourselves in the "city"; only full citizenship will make society stronger. And counseling must be able to relate to this process-that of constructing the "polis," the city. Consequently, counseling must have a political dimension. In sum, we propose that attention to the political context is necessary for effective and comprehensive delivery of learning, education, training, and counseling to the full range of citizens who will need to grapple with the rapidly changing landscape that they face in the postmodern era. 
In our view, the political changes in Portugal within the past 25 years since the fall of fascism provide a sort of naturalistic laboratory of how broader social and cultural forces influence nearly all aspects of career development. As we have described in this article, in Portugal all of these issues are even more dramatic, since we are no longer observing, but now acting in this context. We need a politics of vocations directed to the practice of career counseling focused on the goals of personal empowerment. It is our hope that this article has provided scholars and practitioners with a clearer sense of the complex array of social and political factors that influence vocational behavior. Moreover, we hope that this article will furnish the foundation for a politically informed analysis of career development, a perspective that we believe will be increasingly necessary as we face the rapid changes of the 21 st century.

\section{REFERENCES}

Arthur, M. B., Hall, D. T., \& Lawrence, B. S. (1989). Generating new directions in career theory: The case for a transdisciplinary approach. In M. B. Arthur, D. T. Hall, \& B. S. Lawrence (Eds.), Handbook of career theory. Cambridge, MA: Cambridge University Press.

Black, B. J. (1988). Work and mental health: Transitions to employment. Baltimore: John Hopkins University Press.

Blustein, D. L. (1994). The question of who am I: A cross-theoretical analysis. In M. L. Savickas \& R. W. Lent (Eds.), Convergence in theories of career choice and development. Palo Alto, CA: Consulting Psychologists Press.

Blustein, D. L., Devenis, L. E., \& Kidney, B. A. (1989). Relationship between the identity formation process and career development. Journal of Counseling Psychology, 36, 196-202.

Blustein, D. L., Finkelberg, S., Ketterson, T., Schwam, M., \& Skau, M. (in press). Novas Direcçoes no Desenvolvimento de Carreira (teoria e prática). Cadernos de Psicologia Educacional, Vol. 2 Lisboa: Ediçoes Universitárias Lusófonas.

Blustein, D. L., \& Noumair, D. A. (1996). Self and identity in career development: Implications for theory and practice. Journal of Counseling and Development, 74, 433-441.

Blustein, D. L., Phillips, S. D., Jobin-Davis, K., Finkelberg, S. L., \& Roarke, A. E. (1997). A theory-building investigation of the school-to-work transition. The Counseling Psychologist, 25, $364-402$.

Blustein, D. L., \& Spengler, P. M. (1995). Personal adjustment: Career counseling and psychotherapy. In W. B. Walsh \& S. Osipow (Eds.), Handbook of vocational psychology: Theory, research, \& practice (2nd ed.). Mahwah, NJ: Erlbaum.

Borow, H. (1986). Occupational socialization: Acquiring a sense of work. In N. Gysbers et al. (Eds.), Designing careers. San Francisco, CA: Jossey-Bass.

Boutinet, J.-P. (1986). Le concept de projet et ses niveaux d'apprehension. Education Permanente, 86, 5-26.

Boutinet, J.-P. (1992). Anthropologie du projet. Paris: PUF.

Carlsen, M. B. (1988). Meaning-making: Therapeutic process in adult development. New York: Norton.

Cochran, L. (1990). The sense of vocation: A study of career and life development. Albany: State University of New York Press.

Cochran, L. (1992). The career project. Journal of Career Development, 18, 187-198.

Comissao das Comunidades Europeias (1995). Livro branco sobre a educaçao e formaçao. Ensinar e aprender. Rumo à Sociedade Cognitiva. Bruxelas: Bélgica.

Cushman, P. (1995). Constructing the self, constructing America: A cultural history of psychotherapy. Reading, MA: Addison-Wesley. 
Dalton, G. W. (1989). Developmental views of career in organizations. In M. B. Arthur, D. T. Hall, \& B. S. Lawrence (Eds.), Handbook of career theory. Cambridge, MA: Cambridge University Press.

Diamond, M. (1993). The unconscious life of organizations: Interpreting organizational identity. Westport, CT: Quorum.

Dorn, F. J. (1992). Occupational wellness: The integration of career identity and personal identity. Journal of Counseling and Development, 71, 176-178.

Giddens, A. (1991). Modernity and self-identity. Oxford: Basil Blackwell.

Godet, M. (1991). L'avenir autrement. Paris: Armand Collin.

Hackett, G., \& Lent, R. W. (1992). Theoretical advances and current inquiry in career psychology. In S. D. Brown \& R. W. Lent (Eds.), Handbook of counseling psychology (2nd ed.). New York: Wiley.

Hall, D. T. (1976). Careers in organizations. Santa Monica, CA: Goodyear.

Herr, E. L. (1989). Career development and mental health. Journal of Career Development, 16, 5-18.

Herr, E. L. (1990). Employment counseling in a global economy. Journal of Employment Counseling, 27, 147-159.

Hotchkiss, L., \& Borow, H. (1990). Sociological perspectives on work and career development. In D. Brown, L. Brooks, and associates (Eds.), Career choice and development (2nd ed.). San Francisco, CA: Jossey-Bass.

Kalimo, R., \& Vuori, J. (1991). Work factors and health: The predictive role of preemployment experiences. Journal of Occupational Psychology, 64, 97-116.

Lotto, L. S. (1986). Partnership between education and work. In N. Gysbers et al. (Eds.), Designing careers. San Francisco, CA: Jossey-Bass.

Miller-Tiedeman, A. L., \& Tiedeman, D. V. (1990). Career decision making: An individualistic perspective. In D. Brown, L. Brooks, and associates (Eds.), Career choice and development (2nd ed.). San Francisco, CA: Jossey-Bass.

Miller-Tiedeman, A. L., \& Tiedeman, D. V. (1986). To be in work: On furthering the development of careers and careers development specialists. In N. Gysbers et al. (Eds.), Designing careers. San Francisco, CA: Jossey-Bass.

Neff, W. S. (1985). Work and human behavior (3rd ed.). New York: Aldine.

Nuttin, J. (1987). Developpement de la motivation et formation. Education permanente, 88/89, 97-110.

Nystrom, P. C., \& McArthur, A. W. (1989). Propositions linking organizations and careers. In M. B. Arthur, D. T. Hall, \& B. S. Lawrence (Eds.), Handbook of career theory. Cambridge, MA: Cambridge University Press.

Osipow, S. H. (1979). Occupational mental health: Another role for counseling psychologists. The Counseling Psychologist, 8, 65-70.

Osipow, S. H., \& Fitzgerald, L. F. (1993). Unemployment and mental health: A neglected relationship. Applied and Preventive Psychology, 2, 59-63.

Paixao, M. P., \& Santos, E. (1992, July). Women's career development: report of a field experience in a rural area. Second International Symposium on Career Development, University of Ghent, Belgium.

Richardson, M. S. (1993). Work in people live's. Journal of Counseling Psychology, 40, 425-433.

Sampson, E. E. (1993). Identity politics. Challenges to psychology's understanding. American Psychologist, 48, 1219-1230.

Santos, E., \& Paixao, M. P. (1995). Espaço e temporalidade: A construçao da identidade. Revista Argentina de psicopedagogia, 11(37), 2da etapa, 2-35.

Savickas, M. L. (1991). The meaning of work and love: Career issues and interventions. Career Development Quarterly, 39, 315-324.

Savickas, M. L. (1993). Career counseling in the postmodern era. Journal of Cognitive Psychotherapy: An International Quarterly, 7, 205-215. 
Savickas, M (1995). Uma nova epistemologia para a psicologia vocacional. Cadernos de Psicologia Educacional, Vol. 1, Lisboa: Ediçoes Universitárias Lusófonas.

Savickas, M. L. (1996, August). The career of career. Presented in M. Savickas (Chair), The birth and death of career: Counseling psychology's contribution. Symposium conducted at the meeting of the American Psychological Association. Toronto, Canada.

Savickas, M. L. (in press). The spirit in career counseling: Fostering self completion through work. In D. P. Bloch \& L. J. Richmond (Eds.), The quest for self in work: Connections between spirit and career. Palo Alto, CA: Davies-Black.

Schein, E. H. (1978). Career dynamics: Matching individual and organizational needs. Reading, MA: Addison-Wesley.

Silbereisen, R. K., \& Todt, E. (Eds.) (1993). Adolescence in context: The interplay of family, school, peers, and work in adjustment. New York: Springer.

Ulrich, D. O., \& Lafasto, F. (1995). Organizational culture and human resource management. In G. R. Ferris, S. D. Rosen \& D. T. Barnum (Eds.). Handbook of human resource management. Cambridge, MA: Blackwell.

Vondracek, F. W. (1992). The construct of identity and its use in career theory and research. Career Development Quarterly, 4l, 130-144.

Vondracek, F. W., Lerner, R. M., \& Schulenberg, J. E. (1986). Career development: a life-span development approach. Hillsdale, NJ: Erlbaum.

Watts, A. G. (1992). Enterprise and careers education. Phoenix, 60, (March).

Watts, A. G., Stern, E., \& Deen, N. (1992). Careers guidance towards the 21st century. Cambridge: CRAC.

Young, R. A. (1984). Toward an ecology of career development. Canadian Counsellor, 18, 152-159.

Received: July 30, 1997 